\title{
Selective deficiency of hepatic triglyceride lipase and hypertriglyceridaemia in kwashiorkor
}

\author{
BY E. O. AGBEDANA, A. O. JOHNSON AND G. OLADUNNI TAYLOR \\ Department of Chemical Pathology and Paediatrics, \\ University of Ibadan, Ibadan, Nigeria
}

(Received 27 March I979-Accepted 2 May 1979)

\begin{abstract}
I. Serum postheparin lipolytic activities (PHLA), triglyceride and free fatty acid concentrations were determined in children with kwashiorkor before and after treatment and also in normal control children.

2. Using the range $(571-1650 \mu \mathrm{mol} / \mathrm{l})$ of serum triglyceride of the control children as normal, five $(20 \%)$ of the twenty-five children with kwashiorkor had low (less than $570 \mu \mathrm{mol} / 1)$, thirteen $(52 \%)$ had normal $(571-1650 \mu \mathrm{mol} / \mathrm{l})$ and seven $(28 \%)$ had high (more than $1650 \mu \mathrm{mol} / \mathrm{l})$ serum triglyceride levels.

3. The serum PHLA did not show any definite correlation with the level of circulating triglycerides, although the lowest levels of PHLA were found in the malnourished children with highest triglyceride level.

4. While the hepatic PHLA in the malnourished children was significantly less than control value, the extrahepatic PHLA did not differ significantly.

5. After treatment, serum PHLA rose significantly and the mean levels were within normal range.

6. Our findings suggest that a defect in catabolism of very-low-density lipoprotein caused by a low hepatic PHLA may cause hypertriglyceridaemia in children with kwashiorkor.
\end{abstract}

An elevated serum free fatty acid (FFA) occurs commonly in kwashiorkor, and this has usually been one of the explanations for the fatty liver often found in this condition (Lewis et al. 1964; Fletcher, 1966). Both serum cholesterol and phospholipids are low (Schwartz \& Dean, I957; Macdonald et al. 1963; Rao \& Prasad, 1966) while the serum triglyceride may be normal or reduced (Lewis et al. 1964; Truswell et al. 1969; Flores et al. 1970).

An important mechanism regulating the concentration of circulating blood lipids is believed to involve a complex system in which the enzyme lipoprotein lipase (LPL) plays an important role. LPL is involved in the hydrolysis of lipoprotein-bound triglyceride in the serum and its activity may modify triglyceride transport and distribution to the tissues (Robinson, 1970). LPL is present in tissues such as the heart, adipose tissue, aorta and liver (Desnuelle, 1972; Fredrickson \& Levy, 1972), and the injection of heparin or similar polyionic substances causes its displacement into circulation from the binding sites (Korn, 1959). Serum postheparin lipolytic activity (PHLA) apparently includes at least two major enzymes originating from liver and extrahepatic tissues such as adipose tissue (Krauss et al. 1973), and both enzymes are equally capable of hydrolysing triglyceride-rich lipoproteins (Klose et al. 1977; Mordasini et al. 1977).

The purpose of this study was to determine serum PHLA, triglyceride and FFA in children with kwashiorkor before and after treatment in an attempt to further determine the role of LPL activity in the deranged lipid metabolism which occurs in kwashiorkor.

\section{METHODS}

Patients

Twenty-five children with kwashiorkor, ranging in age from I to 5 years, and ten normal control children within the same age-range were studied. All malnourished patients had typical features of kwashiorkor such as growth failure, hypoalbuminaemia, oedema and characteristic skin and hair changes. The control children were children admitted to the 
hospital for minor surgical elective procedures such as herniorrhaphy. The study protocol was approved by the Ethical Committee of the Department of Paediatrics, Faculty of Medicine, University of Ibadan, Nigeria, and informed consent was obtained from the parents of the children before the commencement of the investigations.

The initial biochemical studies in the malnourished children were carried out as soon as possible after hospital admission but before being started on nutritional rehabilitation. Malnourished children with severe complications like diarrhoea, hypothermia and significant hypoglycaemia were excluded from the study.

After the intial studies, the patients were placed on a diet of skimmed milk with multivitamin and haematinic supplements until they improved enough to take a normal ward (balanced) diet. They were then discharged and cared for as out-patients. At 3-4 months after complete nutritional rehabilitation as evidenced by loss of oedema and satisfactory weight gain, the patients who had not defaulted from the clinic were re-admitted as day cases for repeat studies.

\section{Blood collection and processing of serum}

After an overnight fast 3-5 ml venous blood samples were obtained before and at $10 \mathrm{~min}$ after rapid intravenous injection of Io IU heparin (Evans Medical Ltd, Poole, England) $/ \mathrm{kg}$ body-weight. The blood was collected into a universal bottle in each instance, placed in an ice-bath and allowed to clot. Serum was separated by centrifugation at $4^{\circ}$ and stored at $-20^{\circ}$ until assays of lipolytic activities and other biochemical tests were carried out.

\section{Preparation of triolein emulsion (substrate)}

The triolein emulsion used as substrate in PHLA assays was prepared under strictly standardized conditions. The following components: $3 \mathrm{ml}$ bovine serum albumin (300 $\mathrm{mg})$, glycerol $\left(2-{ }^{3} \mathrm{H}\right)$ trioleate (The Radiochemical Centre, Amersham, Bucks.), triolein (270 mg), lysolecithin $(16.2 \mathrm{mg}), 1.6 \mathrm{ml} 2 \mathrm{M}$-Tris- $\mathrm{HCl}$ buffer $(\mathrm{pH} 8.0$ ) were made up to a total of $6 \mathrm{ml}$ with water, in a beaker. The microtip of a Branson (MSE, London) sonicator was placed approximately $5 \mathrm{~mm}$ below the surface of the solution and the mixture was sonicated in an ice-bath for a total of $8 \mathrm{~min}$ alternating $60 \mathrm{~s}$ sonication with a $60 \mathrm{~s}$ pause. The substrate was activated by incubating with $12 \mathrm{ml}$ heated fasting human serum for $30 \mathrm{~min}$ at $37^{\circ}$ in a water-bath with a shaker. (The fasting human serum was first heated for $10 \mathrm{~min}$ at $62^{\circ}$ in a water-bath to inactivate any endogenous LPL that might have been present in the body.) Freshly prepared substrate was used for each test.

\section{Standard assay for serum PHLA}

The selective measurement of LPL activity was based on inactivation extrahepatic activity by protamine sulphate as originally described by Krauss et al. (1973). In the standard assay,

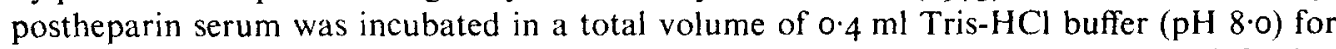
Io min at $37^{\circ}$. After this incubation, $0.6 \mathrm{ml}$ substrate medium was added and further incubation was carried out for $45 \mathrm{~min}$ at $37^{\circ}$. The reactions were terminated by adding $1 \mathrm{ml}$ trichloroacetic acid ( $100 \mathrm{~g} / \mathrm{l} \mathrm{TCA})$. In the assay of hepatic lipase, the samples were also incubated in the same buffer containing protamine sulphate $(3 \mathrm{mg} / \mathrm{o} \cdot 1 \mathrm{ml}$ serum) for $10 \mathrm{~min}$ at $37^{\circ}$. The assay of LPL was then carried out as described previously. In each instance, the $\left({ }^{3} \mathrm{H}\right)$ glycerol extracted into the TCA supernatant was counted in Instagel using a Packard Tricarb liquid-scintillation spectrometer. Total release of fatty acid was calculated and the enzyme activity expressed as nmol fatty acid/ml per min. The extraction of glycerol was $100 \%$ efficient and there was no need for any correction factor in the calculation. The extrahepatic enzyme activity was the difference between total PHLA and hepatic lipase activity. 
Table I. Mean body-weight, serum free fatty acid, triglycerides and postheparin lipolytic activities (PHLA) in children with kwashiorkor and control children*

(Mean values with their standard errors; no. of children in parentheses)

Group . . .

Body-wt (kg)

Triglyceride $(\mu \mathrm{mol} / \mathrm{l})$

Free fatty acid $(\mu \mathrm{mol} / \mathrm{l})$

PHLA

Total (nmol fatty acid/ml per min)

Hepatic (nmol fatty acid/ml per min)

Extrahepatic (nmol fatty acid/ml per min)

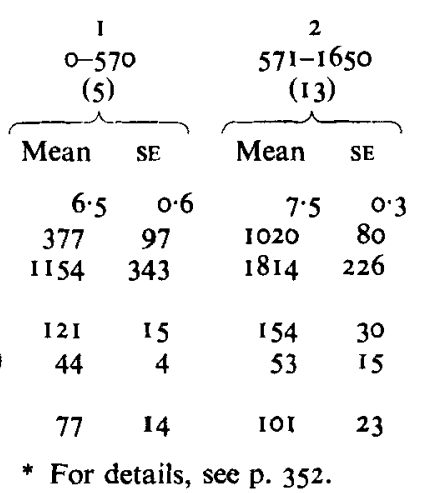

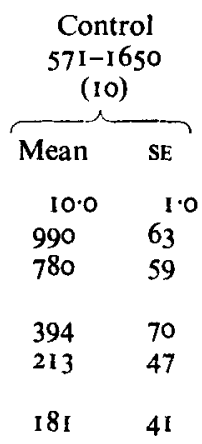

Other biochemical tests

The concentration of triglyceride was measured by the method of Gottfried \& Rosenberg (1973) using triolein (Sigma Co., St Louis, Mo., USA) as standard. Serum FFA was estimated by Dole's titrimetric method as modified by Trout et al. (1960). Thymol blue $(0.01 \%$ in water) was the indicator and palmitic acid (Sigma Co.) was the standard acid used.

\section{Statistical tests}

The mean, standard error of mean and $\chi^{2}$ were calculated using standard methods. The test of significance was carried out using Student's $t$ test; $P>0.05$ was regarded as not significant.

\section{RES ULTS}

The range of serum triglyceride ( $\mu \mathrm{mol} / \mathrm{l}$ ) was $154-42 \mathrm{I} 3$ in the patients with kwashiorkor and 57I-1650 in the control group. Relative to control values, the malnourished children could be classified into three distinct groups based on serum triglyceride levels $(\mu \mathrm{mol} / \mathrm{I})$ : group I with low (0-570) serum triglyceride; group 2 with normal level (57I-1650) and group 3 with high serum triglyceride level (more than 1650 ). The percentage distribution of the patients studied in each of these groups was $20 \cdot 0,52^{\circ} 0$ and $28 \cdot 0$ respectively.

Table I shows that the body-weight tended to increase with increasing level of circulating serum triglycerides and the mean body-weight in group 3 was significantly higher than the value for group I $(P<0.01)$. These values were significantly less than the control value except in group 3, where the reduction was not significant. Also there were no significant differences in serum FFA values in the three groups of malnourished children. These values were significantly higher than the control value except in group I where the increase was not significant (Table 2).

The mean serum total, hepatic and extrahepatic PHLA in the three malnourished groups were not significantly different except that the hepatic PHLA in group 3 was significantly less than the value in group I $(P<0.01)$. The total and hepatic PHLA in these three groups were significantly less, but the reductions in extrahepatic PHLA were not significant when compared with corresponding control values.

In four malnourished children who died during the course of treatment, the mean level 
Table 2. Statistical comparison of body-weights, free fatty acid, postheparin lipolytic activities (PHLA) within and between the groups of children with kwashiorkor (groups $1-3)^{*}$ and control $(C)$ children $\dagger$

$\begin{array}{lcccccc}\text { Groups compared } & \text { I } v .2 & \text { I } v .3 & 2 v .3 & C v .1 & C v .2 & C v .3 \\ \text { Body-wt } & \text { NS } & 0.01 & \text { NS } & 0.05 & 0.02 & \text { NS } \\ \text { Free fatty acid } & \text { NS } & 0.01 & \text { NS } & \text { NS } & 0.001 & 0.002 \\ \text { PHLA: Total } & \text { NS } & \text { NS } & \text { NS } & 0.02 & 0.002 & 0.002 \\ \quad \text { Hepatic } & \text { NS } & 0.01 & \text { NS } & 0.05 & 0.002 & 0.01 \\ \quad \text { Extrahepatic } & \text { NS } & \text { NS } & \text { NS } & \text { NS } & \text { NS } & \text { NS }\end{array}$

NS, not significant $(P>0.05)$.

* Grouped according to serum triglyceride levels $(\mu \mathrm{mol} / \mathrm{l})$ group I $0-570$, group $257 \mathrm{I}-1650$; group 3 $>\mathrm{I} 650$.

$\dagger$ For details, see Table I.

Table 3. Postheparin serum lipolytic activities in children with kwashiorkor before and after treatment

(Control values are shown in parentheses)

PHLA values ( $\mu \mathrm{mol}$ fatty acid $/ \mathrm{ml}$ per $\mathrm{min}$ )

\begin{tabular}{|c|c|c|c|c|c|c|}
\hline \multirow[b]{2}{*}{ Patient } & \multicolumn{3}{|c|}{ Before treatment } & \multicolumn{3}{|c|}{ After treatment } \\
\hline & Total & Hepatic & Extrahepatic & $\begin{array}{c}\text { Total } \\
(394 \pm 70)\end{array}$ & $\begin{array}{c}\text { Hepatic } \\
(213 \pm 47)\end{array}$ & $\begin{array}{c}\text { Extrahepatic } \\
(181 \pm 41)\end{array}$ \\
\hline L.F. & I 54 & 43 & I I I & 474 & 284 & 190 \\
\hline M.S. & $5 I$ & 32 & 19 & 174 & 79 & 95 \\
\hline A.G. & 82 & I4 & 68 & 104 & 87 & 17 \\
\hline L.M. & 101 & 54 & 47 & 299 & 85 & 214 \\
\hline O.A. & 320 & 146 & 174 & 380 & 180 & 200 \\
\hline S.S. & 90 & 37 & 53 & 120 & 57 & 63 \\
\hline F.M. & 97 & I 2 & 85 & 290 & 100 & 190 \\
\hline M.G. & 193 & 48 & 125 & 436 & 222 & 214 \\
\hline
\end{tabular}

of hepatic PHLA was less than the mean level in those who survived. However, there was no significant correlation $\left(\chi^{2}{ }_{1} 3 \cdot 20\right)$ between the number of deaths and reduced hepatic PHLA.

Table 3 shows that in seven of the eight children with kwashiorkor who were studied after full clinical recovery, the total, hepatic and extrahepatic PHLA increased to within normal levels.

\section{DISCUSSION}

This study has shown that in accord with previous reports (Lewis et al. 1964; Fletcher, 1966; Rao \& Prasad, 1966; Flores et al. 1970; Taylor, I97I), the serum FFA is significantly elevated in patients with kwashiorkor. The serum triglyceride concentrations showed wide variations but the over-all mean level was not significantly different from the value in healthy controls. Taking the range of serum triglyceride values in the control children as normal, the malnourished children could be divided into three distinct groups as having low, normal or high serum triglycerides, as previously reported by Flores et al. (1973).

The exact cause of the wide variations in the levels of serum triglycerides among proteinmalnourished children is unknown, but many hypotheses have been suggested. Arroyave et al. (I96I) were of the opinion that the concentration of serum triglyceride may be influenced by the extent of fatty infiltration of the liver, the concentration being lowest in patients with the greatest extent of fatty liver. This view is supported by Truswell (1975). The importance of fatty liver in kwashiorkor is that prognosis in this disorder correlates 
with the extent of fatty infiltration of the liver (Waterlow et al. I960) and the variation in the levels of serum triglyceride may therefore reflect the severity of the disease. In the present study, liver enlargement was observed in the majority of the patients. Although hepatomegaly in kwashiorkor is believed to be due to fatty infiltration of the liver, liver palpation is a poor measure of the extent of fatty liver (Trowell et al. 1954). The relationship between the level of serum triglycerides and severity of protein-malnutrition needs further investigation, although Taylor (1971) did not observe any definite association between the severity of kwashiorkor and serum cholesterol levels.

This study has also shown that the heavier patients had the highest concentration of serum triglycerides, a finding again similar to that of Flores et al. (1973). This tendency to hypertriglyceridaemia in some patients with kwashiorkor may be similar to the lipemia observed in obesity (Gofman, 1954) as some patients with kwashiorkor have more adipose mass than healthy controls (Garrow, 1966).

Dietary habit greatly influences serum lipid patterns in man (Scott et al. 1964) and differences in the type of food consumed by these children may account for the wide variation in serum triglyceride concentrations. However, the commonest weaning diet among the people of low socio-economic group in our environment is maize starch, and therefore the effect of the type of diet may be minimal in the present study.

The role of LPL in triglyceride metabolism in kwashiorkor has hitherto received scant attention. Probably the most remarkable result of this study is that the reduced serum total PHLA in the different groups of kwashiorkor is mostly due to diminished hepatic triglyceride lipase activity.

Furthermore, the serum hepatic triglyceride lipase was lowest in the group of malnourished patients with the highest triglyceride concentrations. The significance of this finding is not immediately clear, as the specific role of hepatic triglyceride lipase in triglyceride metabolism is not definitely known. However, in a number of conditions a secondary hypertriglyceridaemia usually accompanies reduced hepatic triglyceride lipase activity (Klose et al. 1977; Mordasini et al. 1977). In the present study, the majority of the patients had normal or higher than normal levels of serum triglyceride. This has been confirmed in a study involving a large number of malnourished patients (Agbedana \& Taylor, unpublished observation). It is tempting, therefore, to speculate that accumulation of triglyceride-rich lipoproteins in some of the children is a consequence of the demonstrated low hepatic triglyceride lipase activity. This hypothesis does not necessarily imply that the conversion of intermediate lipoprotein to LDL occurs in the liver, but the demonstration of insignificant reduction in extrahepatic triglyceride lipase in all the children with kwashiorkor is strongly in favour of this hypothesis.

In explaining the fatty liver in kwashiorkor many workers have proposed that there is a defective release of very-low-density lipoprotein (VLDL; triglyceride-rich) probably as a consequence of decreased apoprotein synthesis by the liver (Truswell \& Hansen, 1969; Truswell et al. 1969; Coward \& Whitehead, 1972). Thus there are two major opposing factors affecting the levels of circulating triglycerides in kwashiorkor; a decreased release of VLDL causing hypotriglyceridaemia and reduced serum hepatic triglyceride lipase causing hypertriglyceridaemia. Protein-malnourished children with varying extents of triglyceridaemia may be considered as representing different stages of the equilibrium between the rates of release and catabolism of triglycerides. This probably explains why dietary therapy which has been shown to cause release of liver lipids into circulation (Arroyave et al. 196I) leads to a pronounced hypertriglyceridaemia within 2-10 d of dietary rehabilitation in treatment of kwashiorkor followed by a return to normal level at full recovery (Rao \& Prasad, I966; Taylor, I971). Our study has shown that the postheparin serum hepatic triglyceride lipase activity rises rapidly to normal level after recovery in the patients tested. 


\section{E. O. Agbedana, A. O. Johnson and G. O. Taylor}

In the few fatal cases the initial hepatic triglyceride lipase activity tended to be lower than the activity in the patients who survived. The paucity of the number of such patients precluded meaningful comparison of the results in the fatal and non-fatal cases. It has been suggested that liver failure may be an important cause of sudden death among children with severe kwashiorkor (McLean, 1962). It is probable that the changes in the activity of the enzyme may reflect the extent of liver damage, and its measurement may be a very sensitive and useful prognostic test.

In conclusion, our results suggest that in kwashiorkor a defect in catatabolism of VLDL caused by a low serum hepatic triglyceride lipase leads to accumulation of triglyceride-rich lipoproteins. However, in some patients an associated defective release of VLDL probably due to excessive fatty infiltration of the liver prevents the occurrence of hypertriglyceridaemia.

\section{REFERENCES}

Arroyave, G., Wilson, D., Mendez, T., Behar, M. \& Scrimshaw, N. S. (1961). Am. J. clin. Nutr. 9, 180. Coward, W. A. \& Whitehead, R. G. (1972). Br. J. Nutr. 27, 383.

Desnuelle, P. (1972). In The Enzymes of Lipid Metabolism, vol. 7, 3rd ed., p. 575 [P. Boyer, editor]. New York: Academic Press.

Fletcher, K. (1966). Am. J. clin. Nutr. 19, 170.

Flores, H., Park, N., Maccioni, A. \& Monckeberg, F. (1970). Br. J. Nutr. 24, 1005.

Flores, H., Seakins, A. \& Monckeberg, F. (1973). In Dietary Lipids and Postnatal Development, p. II 5. New York: Raven Press.

Fredrickson, D. S. \& Levy, R. I. (I972). In The Metabolic Basis of Inherited Disease, 3rd ed. p. 544 [J. B. Standbury, J. B. Myngaarden and D. S. Fredrickson, editors]. New York: McGraw-Hill.

Garrow, J. S. (1966). Archs Latinam. Nutr. 16, 146.

Gofman, J. W. (1954). Plasma 2, 413.

Gottfried, S. P. \& Rosenberg, B. (1973). Clin. Chem. 19, 1077.

Klose, G., Windelband, J. \& Weizel, A. (1977). (Cited from Mordasini et al. 1977.)

Korn, E. D. (1959). Meth. Biochem. Anal. 7, I45.

Krauss, R. M., Windmueller, H. G., Levy, R. I. \& Fredrickson, D. S. (1973). J. Lipid Res. 14, 286.

Lewis, B., Hansen, J. D. L., Wittman, W., Krut, L. H. \& Stewart, F. (I964). Am. J. clin. Nutr. 15, I61. Macdonald, I., Hansen, J. D. L. \& Bronte-Stewart, B. (1963). Clin. Sci. 24, 55.

McLean, A. E. M. (1962). Lancet ii, 1292.

Mordasini, R., Frey, F., Flury, W., Klose, G. \& Greten, H. (1977). New Engl. J. Med. 297, 1362.

Rao, K. S. \& Prasad, P. S. (1966). Am. J. clin. Nutr. 19, 205.

Robinson, D. S. (1970). In Comprehensive Biochemistry, vol. I 8, p. 5 I [M. Florkin and E. H. Stotz, editors]. New York: Elsevier.

Schwartz, R. \& Dean, R. F. (1957). J. trop. Paediat. 3, 23.

Scott, R. F., Lee, K. T., Kim, D. N., Morrison, E. S. \& Goodale, F. (1964). Am. J. clin. Nutr. 14, 280.

Taylor, G. O. L. (1971). Am. J. clin. Nutr. 24, 1212.

Trout, D. L., Estes, E. H. \& Friedberg, S. J. (1960). J. Lipid Res. I, 199.

Trowell, H. C., Davies, J. N. P. \& Dean, R. F. O. (1954). Kwashiorkor, p. 167. London: Edward Arnold.

Truswell, A. S. (1975). In Protein-Calorie Malnutrition, p. I I9 [R. E. Oslon, editor). New York and London: Academic Press.

Truswell, A. S. \& Hansen, J. D. L. (I969). S. Afr. med. J. 43, 280.

Truswell, A. S., Watson, C. E. \& Wanneburg, P. (I969). Am. J. clin. Nutr. 22, 568.

Waterlow, J. C., Cravioto, J. \& Stephen, J. M. L. (1960). Adv. Prot. Chem. 15, 13 I. 